\title{
DIROFILARIOSIS AND ANGIOSTRONGILOSIS IN PET AND HUNTING DOGS IN NOVI SAD, VOJVODINA, SERBIA
}

Ljubica Spasojević Kosićc ${ }^{1 *}$, Vesna Lalošević ${ }^{1}$, Stanislav Simin ${ }^{1}$, Ljiljana Kuruca ${ }^{1}$

${ }^{1}$ University of Novi Sad, Faculty of Agriculture

${ }^{2}$ Department of Veterinary Medicine, Novi Sad, Serbia

\begin{abstract}
The aim of this study is to update the data on the prevalence of Dirofilaria immitis (D. immitis) and Dirofilaria repens (D. repens) infections in pet dogs, to report a preliminary result of the prevalence of Angiostrongylus vasorum (A. vasorum) in hunting dogs, and to assess the presence of concurrent infection with $D$. immitis and A. vasorum in hunting and pet dogs in Novi Sad. The methods used to estimate the prevalence of dirofilaria infections were modified Knott test and detection of antigen of $D$. immitis. The prevalence of $A$. vasorum was determined using Baermann fecal technique and detection of $A$. vasorum antigen. Concurrent infection with $D$. immitis and $A$. vasorum was assessed only by detection of antigens of each parasite. Overall prevalence values for $D$. immitis and $D$. repens were $18.95 \%$ (24/143) and $16.32 \%$ (27/143), respectively. The prevalence of $A$. vasorum in hunting dogs was $1.96 \%(1 / 51)$. Concurrent infection with $D$. immitis and A. vasorum did not exist in examined hunting and pet dogs. Further studies with larger number of examined dogs and samples from other region of the country are needed to determine the prevalence of these parasites.
\end{abstract}

Key words: Dirofilaria spp., A. vasorum, prevalence, dogs.

\footnotetext{
${ }^{1 *}$ Corresponding author: e-mail: ljubicask@polj.uns.ac.rs
} 


\title{
DIROFILARIOZA I ANGIOSTRONGILOZA KOD PASA KUĆNIH LJUBIMACA I LOVAČKIH PASA U NOVOM SADU, VOJVODINA, SRBIJA
}

\author{
Ljubica Spasojević Kosić ${ }^{1}$, Vesna Lalošević ${ }^{1}$, Stanislav Simin ${ }^{1}$, Ljiljana Kuruca ${ }^{2}$ \\ ${ }^{1}$ Univerzitet u Novom Sadu, Poljoprivredni fakultet \\ ${ }^{2}$ Departman za veterinarsku medicine, Novi Sad, Serbia
}

\section{Kratak sadržaj}

Cilj ovog istraživanja je da pruži nove podatke o prevalenciji $D$. immitis i D. repens kod pasa kućnih ljubimaca u Novom Sadu, da objavi preliminarne rezultate prevalencije $A$. vasorum kod lovačkih pasa u Novom Sadu, i da proceni da li postoji istovremena infekcija sa oba parazita kod lovačkih pasa i pasa kućnih ljubimaca u Novom Sadu. Za procenu prevalencije infekcije dirofilarijama korišćeni su modifikovani Knotov test i detekcija antigena $D$. immitis. Prevalencija A. vasorum je ispitivana kod lovačkih pasa na osnovu Bermanovog testa i detekcijom antigena parazita. Postojanje istovremene infekcije sa $D$. immitis i $A$. vasorum kod lovačkih i pasa kućnih ljubimaca je proveravano samo na osnovu detektovanja antigena oba parazita. Ukupna prevalencija infekcije D. immitis iznosila je 18,95\% (24/143), dok je za D. repens prevalencija bila $16,32 \%$ (27/143). Prevalencija A. vasorum kod lovačkih pasa je bila $1,96 \%$ (1/51). Nije utvrđeno postojanje istovremene infekcije sa $D$. immitis i $A$. vasorum u ispitivanoj populaciji lovačkih i pasa kućnih ljubimaca. Dalja ispitivanja sa većim brojem pasa i uzoraka od pasa iz različitih delova zemlje su potrebna kako bi se odredila prevalencija za ove parazite.

Ključne reči: Dirofilaria spp., A. vasorum, prevalencija, psi.

\section{INTRODUCTION}

Heartworm diseases caused by Dirofilaria immitis (D. immitis) and angiostrongylosis caused by French heartworm Angiostrongylus vasorum (A. vasorum) are canine parasitic diseases affecting mainly the respiratory and cardiovascular system. Both parasites are lungworms having the same primary site of residence - pulmonary arteries, where they can induce severe pathologic alterations. On the other hand, intermediate hosts of these parasites are 
different, thus defining their specific seasonal characteristics. Mosquitoes as intermediate hosts for Dirofilaria spp. determine transmission period of the diseases. In case of A. vasorum, a wide range of terrestrial and aquatic gastropods act as obligatory intermediate hosts. Mild and wet climate is suitable for rapid multiplication of these intervertebrate hosts. Both parasites mostly cause chronic diseases with severe clinical complications such as pulmonary thromboembolism, right-sided heart failure and caval syndrome associated with $D$. immitis infections, whereas verminous pneumonia, right-sided heart failure and bleeding tendencies are associated with A. vasorum. In addition, the diseases are different in their zoonotic potential. D. immitis, capable to form pulmonary nodules in humans, is considered to have a zoonotic potential, while A. vasorum is not a zoonotic agent (Ware, 2011; Morgan and Show, 2010). While canine cardiopulmonary dirofilariosis and pulmonary angiostrongylosis are diseases of obvious clinical importance, D. repens infection, also known as subcutaneous dirofilariosis, is less clinically important in dogs (Scott and Vaughn, 1987). Due to the importance of D. repens in humans, it is upon veterinary profession to deal with this agent as well.

Previous study on the prevalence of dirofilariosis in pet dogs in Novi Sad has shown the increase of $D$. immitis infection and decrease of infection with D. repens (Spasojević Kosić et al., 2012, 2014) as compared with first reports on the prevalence of D. repens infection (Tasić et al., 2008) and mixed infection with both parasites in dogs (Spasojević Kosić et al., 2014). Such significant prevalence rates make the diseases highly important from both epizootical and clinical point of view. Clinical importance of heartworm disease in dogs and zoonotic potential of Dirofilaria spp. prompted us to monitor the prevalence of both parasites among dogs and report data periodically.

Fecal examination technique or sera analysis have been used for studying the prevalence for A. vasorum in dogs also in some surrounding countries including Greece, Hungary, Bulgaria (Papazahariadou et al., 2007; Schnyder et al., 2015; Pantchev et al., 2015). Couple of years ago, the first case of A. vasorum was reported in Posavac hound in Serbia. Moreover, Serbia is abundant with terrestrial and aquatic gastropods proved to be either natural or experimental host for A. vasorum, while climate in Vojvodina offers suitable conditions for their survival (Simin et al., 2014). From the epizootical point of view, this finding is important, yet not sufficient; thus, further studies are needed to estimate the prevalence of canine pulmonary angiostrongylosis among dogs in Serbia. In regions where this disease is endemic, the true prevalence of the disease is probably underestimated, because most diagnoses of angiostrongylosis are made when infection results in clinical signs (Morgan et al. 2005; Koch and 
Willesen, 2009). To our knowledge, this is the first report on the prevalence of A. vasorum in dogs in Serbia. Due to the fact that both heartworm diseases and French heartworm can manifest as subclinical conditions (Savić et al., 2012; Simin et al., 2014) or with respiratory signs such as cough and dyspnea, in this study, we investigated the existence of the concurrent infection in some asymptomatic hunting dogs and in pet dogs with clinical signs. Hence, parasitic infestations of respiratory and cardiovascular system should be considered by a clinician when a differential diagnosis list is made for patients with respiratory and/or cardiovascular system signs.

\section{MATERIAL AND METHODS}

In the period from 2010 to 2016, pet dogs from Novi Sad were tested for dirofilaria infections. The research included 190 privately owned pet dogs. At the moment of testing, the dogs were at least 7 months old, exposed minimally to one mosquito season (in Serbia it is from April to October), and without history of treatment with macrocyclic lactones. All animals were clinically examined and blood samples were taken from all dogs to the purpose of parasitological examination. The parasitological examination consisted of wet blood smears, modified Knott test and antigen testing. Techniques for detecting circulating microfilariae included microscopic examination of fresh blood smears and modified Knott test. Detection and enumeration of circulating microfilariae (mf) of both D. immitis and D. repens were carried out using modified Knott test (Bazzochi et al., 2008). Morphological characteristics of microfilariae such as length, width, cephalic and caudal ends, were assessed in order to differentiate microfilariae of two Dirofilaria species (Genchi et al., 2007). Detection of circulating $D$. immitis antigens was carried out using commercial kit (SNAP Heartworm RT Test, IDEXX Veterinary Diagnostics) according to manufacturer's instruction.

In order to detect infestation with A. vasorum in hunting dogs, Baermann fecal examination method and antigen detection (Angio Detect Test, IDEXX Laboratories) were used. For the detection of the A. vasorum larvae, modified Baermann test was performed (Zajac and Conboy, 2006). A total of 51 hunting dogs were examined for A. vasorum infestation by both Baermann fecal examination and antigen detection. Fecal examinations by Baerman test in dogs were done first. The sera of these dogs were frozen and later tested for A. vasorum antigen.

The number of hunting dogs examined for concurrent infections with heartworm and French heartworm was 37, and the analyses were done by anti- 
gen detections for both parasites (SNAP Heartworm RT Test, Idexx Veterinary Diagnostics and Angio Detect Test, Idexx Laboratories). Twelve pet dogs with respiratory clinical signs (mainly cough and dyspnea) were also evaluated for the infestation with both $D$. immitis and A.vasorum using antigen detection for each parasite.

\section{RESULTS AND DISCUSSION}

In this study as well as in our previous studies (Spasojević Kosić et al., 2012, 2014), we have been applying well established and recognized methods in the diagnosing of dirofilariosis (American Heartworm Society Canine Guidelines, 2014, ESCCAP 2012). Our main criteria for testing a dog included it's classification into the susceptible population with respect to age, exposure to mosquitoes and lack of prophylactic treatment. The number of tested dogs varied throughout the time period, and we observed increase in number of dogs with clinical signs among the susceptible population. Clinical signs observed in dogs included cough, dyspnea, fatigue, cachexia, weakness, syncope, skin nodules, lameness, ascites, neurological signs, with cough and skin nodules being the most common ones. The number of dogs infested with $D$. repens was either higher or equal to the number of dogs infested with $D$. immitis. The exceptions in view of numbers of infested dogs were recorded in 2013, 2015 and 2016, when we observed more dogs infested with D. immitis and dogs infested with both Dirofilaria spp. We started with diagnosing concurrent prevalence of infection with both Dirofilaria spp. among pet dogs in 2013, and for the entire study period the infection was confirmed in 11 dogs (table 1).

Table 1. Prevalence of infection with Dirofilaria spp. as single or mixed infection in pet dogs during the study period

\begin{tabular}{|c|c|c|c|c|}
\hline Year & $\begin{array}{c}\text { Number } \\
\text { of dogs }\end{array}$ & $\begin{array}{c}\text { Prevalence } \\
\text { D. repens }\end{array}$ & $\begin{array}{c}\text { Prevalence } \\
\text { D. immitis }\end{array}$ & $\begin{array}{c}\text { Prevalence } \\
\text { Mixed infection }\end{array}$ \\
\hline 2010 & 39 & $10.26 \%(4 / 39)$ & $5.13 \%(2 / 39)$ & 0 \\
2011 & 16 & $12.5 \%(2 / 16)$ & $12.5 \%(2 / 16)$ & 0 \\
2012 & 26 & $15.38 \%(4 / 26)$ & $11.54 \%(3 / 26)$ & 0 \\
2013 & 39 & $12.82 \%(5 / 39)$ & $15.38 \%(6 / 39)$ & $20.51 \%(8 / 39)$ \\
2014 & 26 & $15.38 \%(4 / 26)$ & $7.69 \%(2 / 26)$ & $3.84 \%(1 / 26)$ \\
2015 & 24 & $4.17 \%(1 / 24)$ & $12.5 \%(3 / 24)$ & 0 \\
2016 & 20 & 0 & $35 \%(7 / 20)$ & $10 \%(2 / 20)$ \\
\hline $2010-2016$ & 190 & $10.53 \%(20 / 190)$ & $13.16 \%(25 / 190)$ & $5.79 \%(11 / 190)$ \\
\hline
\end{tabular}


In order to compare the prevalence reported in this study with the prevalence of dirofilariosis in the previous studies, it is necessary to take into consideration the methods used for the diagnosing of $D$. immitis and $D$ repens infection. Having in mind this fact, we can compare our new results with our previously published results, and with the study of Tasić et al. (2008). In this study, we observed an overall prevalence for D. repens of $16.32 \%$ (31/190), which is lower than that from our previous study $(18.88 \%, 27 / 143$ dogs) (Spasojević Kosić et al., 2014) and lower than that from the first report of D. repens in dogs in Novi Sad (Tasić et al., 2008). The prevalence of D. immitis in dogs is $18.95 \%$ $(36 / 190)$, which is higher than that reported in our previous study $(16.78 \%$, $24 / 143$ dogs). The prevalence of $D$. immitis is particularly increased in this year, which could be explained by the fact that the majority of dogs examined in this year were those with respiratory clinical signs. For the period 20092013, the prevalence of dirofilariosis in Vojvodina was reported by Savić et al. (Savić et al., 2014.); however, in this study, the differentiation of microfilariae has not been done and no conclusion can be made on the prevalence of $D$. immitis and D. repens. In the study of Savić et al. (2015), the prevalence of dirofilariosis, being $15.29 \%$, was established for the period of 2 years of study, and in $92.3 \%$ of positive samples, $D$. immitis were determined by PCR.

In order to diagnose $A$. vasorum, Baermann fecal examination technique was used because the test is useful when larvae are being shed. In hunting dogs examined by this test, $A$. vasorum larvae have been detected in one dog (Simin et al., 2014) making the prevalence for A. vasorum of $1.96 \%$. Prevalence of $1.1 \%$ was found in Greece based on fecal examination of 281 samples (Papazahariadou et al., 2007), while the prevalence determined in 1247 dogs from Hungary ranged from $1.36 \%$ to $2.73 \%$ (depending on sera analyses) (Schnyder et al., 2015). In 167 sera of dogs from Bulgaria, no positive findings were recorded (Pantchev et al., 2015). Overall estimated prevalence in this region of Europe in not so high, but the number of examined dogs was higher as compared with our study population. Having in mind that some dogs might not be shedding larvae at the moment of examination, we wanted to increase a detection of infestation with $A$. vasorum by using the detection of the parasite's antigen. However, the antigen of $A$. vasorum was confirmed in none of these animals, not even in the dog in which the larvae of the parasite were detected. The possible explanation for this result could be the formation of antigen-antibody complexes, which inhibit detection of antigen in a sample as it has been previously shown with $D$. immitis detection (Matsumura et al., 1986; Brunner et al., 1988) and with $A$. vasorum detection by rapid device (Schnyder et al., 2014).

In hunting dogs examined for antigen of both parasites, only low level of 
heartworm antigen was detected in two dogs, indicating the prevalence of $D$. immitis in examined hunting dogs of $5.40 \%(2 / 37)$. Concurrent infection with D. immitis and A. vasorum was established in neither hunting nor pet dogs. In Portugal, where the aforementioned study was conducted, concurrent infection with D. immitis and A. vasorum was found in one dog (Alho et al., 2014).

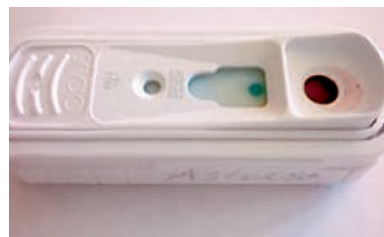

A

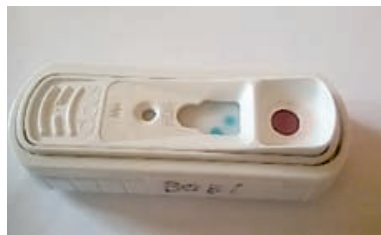

B

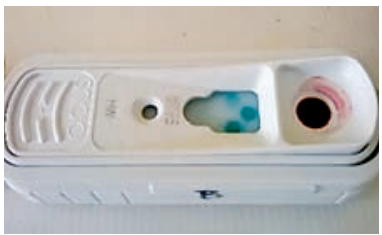

C

Fig 1. SNAP Heartworm RT Test: (A) negative (one dot) and positive findings: (B) two dots (low level) and (C) three dots (high antigen level)

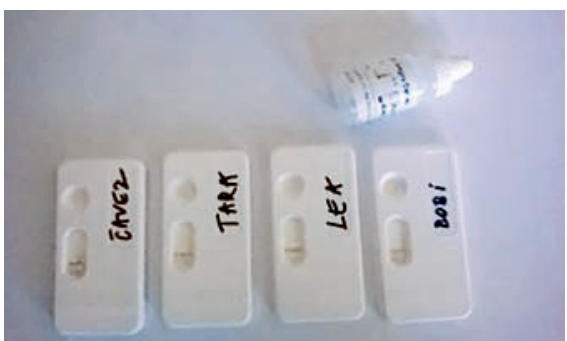

Fig 2. Angio Detect test - showing negative findings (one line) in several pet dogs

Further studies are needed to determine the actual prevalence of $A$. vasorum in dogs in Serbia. Studies like these, aimed at emphasizing the need for specific diagnosis and prevention in dogs, could be useful for clinical practice. With regard to proven heartworm disease and A. vasorum finding in Serbia, use of specific diagnostic procedures for detection of these two parasites in dogs with signs indicating respiratory disease is essential. This approach would provide reliable results of clinical studies on dogs.

\section{CONCLUSION}

This study revealed the prevalence rates of $13.16 \%$ and $10.53 \%$ for single infections with $D$. immitis and $D$. repens, respectively, whereas the prevalence for mixed infections with both Dirofilaria species in pet dogs in Novi Sad was 
$5.79 \%$. Prevalence of D. immitis in hunting dogs was $5.40 \%$. According to the results of Baermann fecal examination method, the prevalence of $A$. vasorum in hunting dogs from Novi Sad was $1.96 \%$. Concurrent infection with $D$. immitis and A. vasorum was established in neither hunting nor pet dogs in Novi Sad, Vojvodina, Serbia.

\section{ACKNOWLEDGEMENTS}

This research is a part of project TR31084 supported by the Ministry of Education, Science and Technological Development of the Republic of Serbia

\section{REFERENCES}

1. Alho A.M., Schnyder M., Meireles J., Belo S., Deplazes P., Madeira de Carvalho L.: Preliminary results on the seroprevalence of Angiostrongylus vasorum and co-infection with Dirofilaria immitis in shelter dogs from Portugal. Parasites \& Vectors, 7, Suppl 1, O26, http://www.parasitesandvectors. com/content/7/S1/O26, 2014.

2. American Heartworm Society: Current Canine Guidelines for the prevention, Diagnosis and management of heartworm (Dirofilaria immitis) infection in dogs 2014. https://www.heartwormsociety.org/images/ pdf/2014-AHS-Canine-Guidelines.pdf, 2014.

3. Bazzocchi C., Mortarino M., Grandi G., Kramer L.H., Genchi C., Bandi C., Genchi M., Sacchi L., McCall J.W.: Combined ivermectin and doxycycline treatment has microfilaricidal and adulticidal activity against Dirofilaria immitis in experimantally infected dogs. International Journal of Parasito$\log y, 38,1401-1410,2008$.

4. Brunner C.J., Hendrix C.M., Blagburn B.L., Hanrahan L.A.: Comparison of serologic tests for detection of antigen in canine heartworm infections. Journal of American Veterinary Medicine Association, 192, 10, 1423-1427, 1988.

5. ESCCAP: Control of vector-borne diseases in dogs and cats. ESCCAP Guideline 05 Second Edition, October 2012, http://www.esccap.org/ page/G5+Control+of+VectorBorne+Diseases+in+Dogs+and+Cats/29/\#. VFNY8vnF98E, 2012.

6. Genchi G., Venco L., Genchi M.: Guideline for the laboratory diagnosis of canine and feline Dirofilaria infections. Mappe Parassitologighe 8, Dirofilaria, 137-145, 2007.

7. Koch J., Willesen J.: Canine pulmonary angiostrongylosis: an update. Veterinary Journal, 179, 348-359, 2009. 
8. Matsumura K., Kazuta Y., Endo R., Tanaka K., Inoue T.: Detection of circulating immune complexes in the sera of dogs infected with Dirofilaria immitis, by Clq-binding enzymelinked immunosorbent assay. Journal of Helminthology, 0, 3, 239-243, 1986.

9. Morgan R.E., Shaw E.S., Brenan F., De Wall D.T.: Angiostrongylus vasorum: a real heartbreaker. Trends Parasitology, 21, 49-51, 2005.

10. Morgan R.E., Shaw E.S.: Angiostrongylus vasorum infection in dogs: continuing spread and developments in diagnosis and treatment. Journal of Small Animal Practice, 51, 616-62, 2010.

11. Pantchev N., Schnyder M., Globokar Vrhovec M., Schaper R., Tsachev I.: Current surveys of the seroprevalence of Borrelia burgdorferi, Ehrlichia canis, Anaplasma phagocytophilum, Leishmania infantum, Babesia canis, Angiostrongylus vasorum and Dirofilaria immitis in Dogs in Bulgaria. $\mathrm{Pa}$ rasitology Research, 114, Suppl 1, S11-S1, DOI 10.1007/s00436-015-45188, 2015.

12. Papazahariadou M., Founta A., Papadopoulos E., Chliounakis S., Antoniadou-Sotiriadou K., Theodorides Y.: Gastrointestinal parasites of shepherd and hunting dogs in the Serres Prefecture, Northern Greece. Veterinary Parasitology, 148, 170-173, 2007.

13. Savić S., Vidić B., Grgić Ž., Jurišić A., Curčić V., Ružić M., Lolić Z.: Vektorske zoonoze pasa u Vojvodini / Canine vector borne zoonoses in Vojvodina. Archive of veterinary Medicine, 5, 77-87, 2012.

14. Savić S., Vidić B., Grgić Ž., Petrović T., Potkonjakć, A., Ćupina A., Vaselek S., Petrić D.: Dirofilariosis and leishmaniasis in the northern region of Serbia. INTECH, Chapter 6, http://dx.doi.org/10.5772/61761, 2015.

15. Savić S., Vidić B., Grgić Ž., Potkonjak A., Spasojević Kosić Lj.: Emerging vector borne diseases-incidence through vectors. Frontiers in Public Health, doi:10.3389/fpubh.2014.00267, 2014.

16. Schnyder M., Schaper R., Lukács Z., Hornok S., Farkas R.: Combined serological detection of circulating Angiostrongylus vasorum antigen and parasite-specific antibodies in dogs from Hungary. Parasitology Research, 114, Suppl 1, S145-S154, DOI 10.1007/s00436-015-4520-1, 2015.

17. Schnyder M., Stebler K., Naucke T.J., Lorentz S., Deplazes P.: Evaluation of a rapid device for serological in-clinic diagnosis of canine angiostrongylosis. ParasiteseVectors, 7, 72, doi:10.1186/1756-3305-7-72, 2014.

18. Scott D.W., Vaughn T.C.: Papulonodular dermatitis in a dog with occult filariasis. Companion Animal Practice, 1, 32-34, 1987.

19. Simin S., Spasojević Kosić Lj., Kuruca Lj., Pavlović I., Savović M., Lalošević V.: Moving the boundaries to the south-east: first record of autochthonous 
Angiostrongylus vasorum in a dog in Vojvodina province, northern Serbia. Parasites\& Vector, 7, 396, 2014.

20. Spasojević Kosić Lj., Lalošević V., Lalošević D., Simin S., Vasić I., Kuruca $\mathrm{Lj.:}$ Prevalence of dirofilariosis in pet dogs in Novi Sad. Contemporary agriculture, 61, 3-4, 247-254, 2012.

21. Spasojević Kosić Lj., Simin S., Lalošević V., Lalošević D., Kuruca Lj., Nikolić S., Nerac D.: Updating the prevalence of dirofilariosis in pet dogs in Novi Sad, Vojvodina, Serbia, Contemporary agriculture, 63, 4-5, 487-493, 2014.

22. Tasić A., Rossi L., Tasić S., Miladinović-Tasić N., Ilić T., Dimitrijević, S.: Survey of canine dirofilariasis in Vojvodina, Serbia. Parasitology Research, 103, 1297-1302, 2008.

23. Ware W.: Heartworm disease. In: W. Ware, Cardiovascular disease in small animal disease, London: Manson Publishing/The veterinary press, 2011, pp.351-371.

24. Zajac A.M., Conboy G.A.: Veterinary clinical parasitology. Oxford, Blackwell Publishing, 2006.

Primljeno: 15.09.2016.

Odobreno: 25.12.2016. 